\title{
A Proposed Educational Vision For Activating The Role of The Jordanian Universities Students Families In Enhancing Students Intellectual Security From The Students Perspectives
}

\author{
Khloud Falah Ahmad Rahamneh \\ Prof. Mohammed Amin" Hamed Al- Qudah \\ AL-Balqa Applied University, Princess Rahma University, Jordan
}

doi: 10.19044/esj.2016.v12n16p105 URL:http://dx.doi.org/10.19044/esj.2016.v12n16p105

\begin{abstract}
This study aimed to find out the role of the Jordanian families in establishing intellectual security in their children from the perspective of the Jordanian students enrolled in Jordanian universities. For this purpose, a questionnaire of 36 paragraphs was created. The questionnaire was divided into three domains: the social, the cultural and the religious domains. The study was conducted on a random sample of (2700) students from three public universities (the University of Jordan, Yarmouk University, Moa'ta University and Al-Balqa' Applied University) and three private universities (Amman Al-Ahliah, Azzaytouna al-Ordiniah and Jerash). The study was conducted during the second university term of 2015/2016 CE. The descriptive analytical approach was used. The study showed that the three domains (social, cultural and religious) were of high degree. The highest of them was the cultural domain. The two paragraphs which state (the family's quest to build a cultural system emerging from our religion, values, traditions and customs, consolidating the values of the theoretical and practical dimensions of moderation among children) occupied the first rank, followed by the social domain. The paragraph which states that (The family's doing its basic function of education and socialization) occupied the first rank, whereas the religious domain occupied the last one. The paragraph which states (The family's seeking to form the right belief at an early age) occupied the first rank.
\end{abstract}

Keywords: Intellectual security, Family, students, in Jordanian universities, social domain, cultural domain, religious domain 


\section{Introduction}

Security is an urgent need for the sustainability and regularity of life. Countries can never be, nor will have stability or progress without security particularly in the age of successive developments and changes in all political, economic, social and cultural domains. Security, in all its aspects, is always a significant requirement sought by individuals and countries all over times and places. The most prominent type of security is the one related to the human's thought, behaviour and perspective towards things and the way to judge them. This is what has become termed as intellectual security.

The importance of intellectual security has recently emerged as a result of the world terror incidents which threatened societies both intellectually and in security, particularly when terrorism consequences affected the intellectual components of societies. Intellectual security is no longer linked only to forcing strict rules, but it has exceeded that to include creating various, cultural and intellectual environments through activating the cultural and intellectual aspects in addition to asserting the importance of dialogue, acceptance of others and living with them.

Family is the first social institution that receives the child since birth and where the child receives his society's values, traditions and customs. It also shapes the child's personality through the sort of education and upbringing he is exposed to. Moreover, the family is considered to be the first school where the child acquires the language of his nation. Moreover, it is also responsible for the child's upbringing and guidance in partnership and cooperation with educational systems. However, the family often reflects its orientation and cultural values in addition to its special traditions and customs that connect its members together on society. The family also represents the individuals' identity reference framework in terms of social personality, religion, citizenship and country. (Al-omar, 1994).

\section{The study problem and questions}

Intellectual security is considered to be one of the recent issues in terms of discussion and rooting as it is extremely important for individuals, families and communities. It is considered to be the most important type of security as it cares for the thought of both the individual and the community alike and it is the main pillar for society structure and prosperity and for building personal decency (Ashareefain, Matalqa, Masaada, 2015)

Proper thought is considered to be the backbone and the cornerstone for society and family security. Therefore, the importance of the family and its role in consolidating intellectual security among children is a collective responsibility that is not confined to a particular part, but shared by all society's institutions starting with the small educational institution represented by the family and the other society institutions like the mosque 
to other educational institutions, clubs and mass media. That is because the family is the first social environment where the child starts to form itself before moving into other institutions. (Aljahni, 2016).

The family plays a significant role in originating the concept of intellectual security among children in order to protect them against the current intellectual deviations of this time (Talib, 2005) believing that intellectual security pillars must be consolidated in every home so that it will become an example for producing generations capable of facing intellectual deviations and achieving intellectual security. The study problem presents a proposed educational vision for activating the role of the Jordanian university students' families in their children's intellectual security through answering the following question:

What is the role of the families of the Jordanian students enrolled in Jordanian universities in promoting intellectual security in their children from the students' own perspective?

\section{The importance of the study}

This study, as far as the researcher is aware of, is one of the rare studies that proposes an educational vision for activating the role of the families of the Jordanian students enrolled in the Jordanian universities in intellectual security from the perspective of the students themselves, as the issue of intellectual security seems to be strongly attached to the family which represents the front defense line for the society security. The family is the first channel of protection and the sensing indicators

The importance of the study appears in:

1. The issue of intellectual security against the threatens endangering peoples and governments all over the world is getting more and more important for most countries.

2. Clarifying the role of the families of the students enrolled in Jordanian universities in building intellectual security in their children.

\section{Objectives of the study}

The study aims to explore the role of the Jordanian family in building intellectual security in its children from the perspective of the Jordanian university students.

\section{The study methodology}

The descriptive analytical approach was applied. Means and standard deviation were used. 


\section{Study terms}

1. Vision: a mental image of the desired future within the available possibilities that are likely to be gained in the future, defining the current opportunities and predicting future opportunities. (Al-Gazzawi and others, 2000)

\section{Intellectual Security}

A modern term which means preparing the individual properly and comprehensively according to the Holy Qur'an and Assonna Annabwiah for building the human's thought in different domains : religious, social and intellectual. (Nasser, 2010, P 12).

Intellectual security is "the joint activities and regulations between the state and the society in order to spare individuals and groups beliefs, thoughts or psychological impurities that could be the reason for behavior and thought delinquency or a reason for getting trapped in perils". (Naseer, 2010. P 12)

\section{The study limits}

\section{Human limits}

The study was conducted on a sample of (2700) undergraduate students enrolled in public and private Jordanian universities during the second term of 2015/2016.

\section{Spatial limits}

The study was conducted on the public universities (University of Jordan, Al-Yarmouk University, Mo'ta, Al-Balqa' Applied University) in addition to private universities (Amman Al-Ahliah, Azzaitouna, Jerash).

Time limits: The study was conducted during the university academic year 2015/2016.

\section{The study limitations}

The current study findings are determined by the psychometric characteristics of the study instrument.

\section{Foundations of intellectual security}

The process of building intellectual security is based on an integrated vision to achieve it. This requires a sort of induction that leads to certainty in addition to studying the concepts that intersect with intellectual security. Because the issue of intellectual security does not depend on only a single factor but on a combination of factors that make up the proper base for promoting intellectual security particularly these days as communities have become in a bad need for building a solid intellectual security system 
meanwhile the nation is undergoing a state of instability as a result of ideological invasion, religious, psychological and media wars in addition to the vast information revolution and the development of means communication. (Hreiz, 2005)

The most important foundations and principles on which intellectual security is based as viewed by (Alotaibi, 2009).

- $\quad$ Adherence to the Holy Qur'an and the Sunnah of his messengerpeace be upon him- as they are the solid fort and strong protection.

- $\quad$ Encouraging people to speak their minds as this leads to thinking and critical thinking in particular.

- $\quad$ Encouraging purposeful dialogue, explaining points of view and respecting others' views.

- Having good morals as they are a strongly rooted body inside character. This body of ethics guides its owner to behave well in saying and in deeds as well. The steadiness of ethics means they are not subject to change or substitution.

- $\quad$ Renewal of religious discourse in line with the time developments.

- Activating the role of all establishments of socialization, like the family, the mosque, mass media, educational institutions (schools and universities) and curricula in promoting intellectual security.

The family and intellectual security, the role of the family in promoting intellectual security

\section{The relation between the family and intellectual security}

The relation between the family and intellectual security is extremely strong. As the family is the first incubation where the individual grows up and receives his thoughts and where his attitudes and intellectual security are usually constructed. The family is the first social institution with which the individual interacts and from which takes his values, traditions and customs, and through which his personality is built. (Aljehni, 2004)

Security and the family complement each other through the role which the family plays in strengthening the individual's cultural identity, proper upbringing of individuals in accordance with the society and family foundations, a sort of education based on doctrine and ethical foundations that provide intellectual security to individuals and help them choose the right path to take.

According to Abu (Hmeidi, 2014) the role of the family in promoting intellectual security among individuals is a main base for society security because the family is the society's main stone. A good family produces a good society and vice versa. 
The solid foundations of the family will inevitably support society security and is reflected on social life as a result. Therefore, it contributes to creating a good environment for growth and development.

(Al-Jehni, 2004) pointed out that the family is the seed of the community and the incubator of the individual and it is the appropriate environment for the individual's psychological, social and physical growth. The family is an influential factor in shaping the characters of children through providing them with experiences and attitudes towards many issues in addition to its attitude towards acceptable and nonacceptable behaviors. It is the first institution that is responsible for building self- reliant individuals who can distinguish between right and wrong in light of the system of values and ethics received from the family.

Abu (Hmeidi, 2014), sates that only the family is capable of providing the psychological atmosphere of love and passion and that is reflected on the individuals' feeling of satisfaction and stability. Lack of love between family members generates hatred, rage and leads to family breakdown. And this in turn influences society. Intellectual security is reinforced when the family introduces the right belief in Allah (God) unification, doing all deeds of worship in the right concept, morals like justice, mercy, inviting the young to manipulate their free time in acquiring knowledge and working on purifying thought from corrupt.

\section{The role of the family in reinforcing intellectual security}

Intellectual security has become a top priority in countries' policies especially after the invasion of destructive ideas of modern societies. Some individuals and communities began to construct a set of extremist, deviant beliefs contradicting monotheistic religions. Therefore, challenges and perils endangering individuals and nations increased as a result of adopting such thoughts by some people. So reinforcing intellectual security in the family has become the front defense line which protects the individual's thought against corrupt beliefs and contributes to security and stability. (Abu Hmeidi, 2014)

(Al-Jehni, 2004) stated that the issue of intellectual corruption among the youth of today resulted from a number of reasons as weakness of communication between parents and children and the absence of dialogue among family members. Moreover, there are other reasons related to means of communication, reasons related to readings, reasons related to free time. In addition to parents' wrong behaviors towards their children, like:

- $\quad$ Lack of children follow up

- $\quad$ Controlling and selfish upbringing

- $\quad$ Misuse of entertainment and amusement resources 
- Wrong methods of treatment like either too much firmness or too much tenderness.

- $\quad$ The nature of relationship between couples on the one hand and with their children on the other hand.

- $\quad$ Awareness of parents' rights and their duties towards the family and children, as well.

The researcher suggests that among the components of settled living is people's living in secure societies where they feel assured about the components of their authenticity, qualitative culture and intellectual system. Intellectual security is one of the most important and main pillars for any society.

Especially in the age of globalization, tremendous technological development and cultural invasion of all sorts. This requires building a strong system of thought, belief and ethics. A system that can withstand in the face of these successive temptations and destructive intellectual outside tendencies.

\section{Previous studies}

Some studies have been conducted on the role of socialization institutions in promoting intellectual security including the role of the family.

Al-Jehni study (2004) aimed at identifying the function of the family in promoting intellectual security. The researcher used the analytical descriptive approach to show the role of the family in promoting intellectual security. The study showed the role of the family in taking the responsibility of spreading awareness among children and bringing them up properly in terms of proper logical thinking as well as correcting distorted notions as the family is the first social system that links all individuals with society and with other social, economic, political and psychological systems and achieving intellectual security for the family members. The study showed that the character of the youth is shaped through the ways they are treated by their families, and the type of treatment is reflected on their characters. The study also found out that the nature of relationship between adolescents and their parents is suffering from a critical problem due to fathers' and mothers' ignorance of their responsibilities in protecting their children against intellectual corruption and the absence of dialogue and effective listening between children and parents led to behavioral disorders including intellectual corruption in the forefront.

(Abu Hmeidi, 2014) study aimed to identify the family's contribution to intellectual security through children's moral, worship and belief foundations. The researcher used the descriptive approach to show the role of the family in achieving intellectual security. He also used the conductive method through which he made great mental and psychological efforts in 
studying the texts in order to find out educational principles supported by clear evidence. The study came up with a number of findings, the most important of them are: the Islamic upbringing assured the role of the family in intellectual security through raising children according to Aqeedah (doctrine) foundations in light of the Holy Quraan and the Prophet's Sunnah during his lifetime, in addition to the family and children being liberated from the influential restrictions providing they keep committed to the teachings of Islam without prejudice to any doctrine , opinion or tendency.

(Ashareefain, 2015) study aimed to clarify the concept of intellectual security and the content of educational curricula and showing the importance of both the individual and the society and stating the criteria for selecting the content of educational curricula that achieve intellectual security, then the suggested strategy for the role of educational content in achieving intellectual security. The researcher implemented the descriptive approach and the inductive analytical approach and the deductive approach, as well. The study concluded that intellectual security is providing the atmosphere and circumstances for feeling secure and trust in the light of a group of notions, principles and beliefs which one believes in, in addition to the foundations of building intellectual security are the religious, intellectual and social foundations.

\section{Conclusion}

The study conclusions related to the question" Disclosure of the role of the Jordanian family in building intellectual security among its children from the perspective of the students of Jordanian universities.

In order to answer this question, the following were used: the mean, the standard deviations, ordering, working out the domains related to the proposed educational vision for activating the role of the families of the Jordanian students enrolled in Jordanian universities in their children's intellectual security from the students' perspectives, for each paragraph, and the tables (1), (2), (3), (4) showed the following:

Table (1) shown theMeans and standard deviations for each of the study domains

\begin{tabular}{|c|c|c|c|c|c|}
\hline $\begin{array}{c}\text { Domain } \\
\text { number }\end{array}$ & Domain & Mean & $\begin{array}{c}\text { Standard } \\
\text { deviation }\end{array}$ & Order & Value \\
\hline 2 & $\begin{array}{c}\text { Cultural } \\
\text { domain }\end{array}$ & 4.5188 & .35992 & 1 & high \\
\hline 1 & $\begin{array}{c}\text { Social } \\
\text { domain }\end{array}$ & 4.5061 & .33102 & 2 & high \\
\hline 3 & $\begin{array}{c}\text { Religious } \\
\text { domain }\end{array}$ & 4.4989 & .40374 & 3 & high \\
\hline Total & & 4.5087 & 34179. & & high \\
\hline
\end{tabular}


Table (3) shows that the three domains were of a high value, and the highest value was that of the cultural domain with a mean of (4.5188) and a standard deviation of (.35992), followed by the social domain with a mean of (4.5061) and a standard deviation of (.33102). The religious domain was in the last rank with a mean of (4.4989) and a standard deviation of (.40374). However, the total value of the three domains together was high with a mean of (4.5087)and a standard deviation of (.34179). The paragraphs of each domain were studied as follows:

\section{First: The social domain}

The frequencies, percentages, means, standard deviations, ranks, and values for each paragraph of the social domain were worked out. /the results were as follows:

Table (2) shows frequencies, percentages, mean, standard deviation and rank for the social domain paragraphs.

\begin{tabular}{|c|c|c|c|c|c|c|c|c|}
\hline $\begin{array}{c}\text { Paragraph } \\
\text { no. }\end{array}$ & Paragraph text & $\begin{array}{c}\text { Answer } \\
\text { Level }\end{array}$ & Freq. & $\%$ & $\bar{X}$ & St.d & Order & Rank \\
\hline \multirow{5}{*}{1} & \multirow{5}{*}{$\begin{array}{l}\text { The family } \\
\text { performing its } \\
\text { essential function in } \\
\text { education and } \\
\text { socialization }\end{array}$} & $\begin{array}{l}\text { Strongly } \\
\text { disagree }\end{array}$ & - & - & \multirow{5}{*}{4.64} & \multirow{5}{*}{.495 } & \multirow{5}{*}{1} & \multirow{5}{*}{ High } \\
\hline & & Disagree & - & - & & & & \\
\hline & & Neutral & 19 & .7 & & & & \\
\hline & & Agree & 936 & 34.7 & & & & \\
\hline & & $\begin{array}{c}\text { Strongly } \\
\text { agree }\end{array}$ & 1745 & 64.6 & & & & \\
\hline \multirow{5}{*}{2} & \multirow{5}{*}{$\begin{array}{c}\text { Using proper } \\
\text { orientation instead } \\
\text { of physical } \\
\text { punishment }\end{array}$} & $\begin{array}{l}\text { Strongly } \\
\text { disagree }\end{array}$ & - & - & \multirow{5}{*}{4.45} & \multirow{5}{*}{.553} & \multirow{5}{*}{9} & \multirow{5}{*}{ High } \\
\hline & & Disagree & - & - & & & & \\
\hline & & Neutral & 78 & 2.9 & & & & \\
\hline & & Agree & 1323 & 49.0 & & & & \\
\hline & & $\begin{array}{c}\text { Strongly } \\
\text { agree }\end{array}$ & 1299 & 48.1 & & & & \\
\hline \multirow{5}{*}{3} & \multirow{5}{*}{$\begin{array}{l}\text { Enhancing love of } \\
\text { country home and } \\
\text { defending it against } \\
\text { all threats } \\
\text { contributes to } \\
\text { promoting } \\
\text { intellectual } \\
\text { security. }\end{array}$} & $\begin{array}{l}\text { Strongly } \\
\text { disagree }\end{array}$ & - & - & \multirow{5}{*}{4.59} & \multirow{5}{*}{.506} & \multirow{5}{*}{2} & \multirow{5}{*}{ High } \\
\hline & & Disagree & - & - & & & & \\
\hline & & Neutral & 19 & .7 & & & & \\
\hline & & Agree & 1074 & 39.8 & & & & \\
\hline & & $\begin{array}{l}\text { Strongly } \\
\text { agree }\end{array}$ & 1607 & 59.5 & & & & \\
\hline \multirow[t]{5}{*}{4} & \multirow{5}{*}{$\begin{array}{l}\text { Enhancing values } \\
\text { of tolerance among } \\
\text { the family members }\end{array}$} & $\begin{array}{l}\text { Strongly } \\
\text { disagree }\end{array}$ & - & - & \multirow{5}{*}{4.58} & \multirow{5}{*}{.508} & \multirow{5}{*}{3} & \multirow{5}{*}{ High } \\
\hline & & Disagree & - & - & & & & \\
\hline & & Neutral & 19 & .7 & & & & \\
\hline & & Agree & 1106 & 41.0 & & & & \\
\hline & & $\begin{array}{c}\text { Strongly } \\
\text { agree }\end{array}$ & 1575 & 58.3 & & & & \\
\hline & $\begin{array}{c}\text { Applying the } \\
\text { principle of justice }\end{array}$ & $\begin{array}{l}\text { Strongly } \\
\text { disagree }\end{array}$ & - & - & 4.49 & .585 & & \\
\hline
\end{tabular}




\begin{tabular}{|c|c|c|c|c|c|c|c|c|}
\hline \multirow[t]{4}{*}{5} & \multirow{4}{*}{$\begin{array}{l}\text { and equity in } \\
\text { treatment with the } \\
\text { family members }\end{array}$} & Disagree & - & - & & & \multirow{4}{*}{9} & \multirow[t]{4}{*}{ High } \\
\hline & & Neutral & 124 & 4.6 & & & & \\
\hline & & Agree & 1124 & 41.6 & & & & \\
\hline & & $\begin{array}{l}\text { Strongly } \\
\text { agree }\end{array}$ & 1452 & 53.8 & & & & \\
\hline \multirow{5}{*}{6} & \multirow{5}{*}{$\begin{array}{l}\text { Strengthening the } \\
\text { values of } \\
\text { cooperation } \\
\text { between the family } \\
\text { members }\end{array}$} & $\begin{array}{l}\text { Strongly } \\
\text { disagree }\end{array}$ & - & - & \multirow{5}{*}{4.59} & \multirow{5}{*}{.547} & \multirow{5}{*}{2} & \multirow{5}{*}{ High } \\
\hline & & Disagree & - & - & & & & \\
\hline & & Neutral & 77 & 2.9 & & & & \\
\hline & & Agree & 951 & 35.2 & & & & \\
\hline & & $\begin{array}{l}\text { Strongly } \\
\text { agree }\end{array}$ & 1672 & 61.9 & & & & \\
\hline \multirow{5}{*}{7} & \multirow{5}{*}{$\begin{array}{l}\text { Enhancing genuine } \\
\text { values like } \\
\text { honoring kinship } \\
\text { and filial piety }\end{array}$} & $\begin{array}{l}\text { Strongly } \\
\text { disagree }\end{array}$ & - & - & \multirow{5}{*}{4.27} & \multirow{5}{*}{.561} & \multirow{5}{*}{12} & \multirow{5}{*}{ High } \\
\hline & & Disagree & - & - & & & & \\
\hline & & Neutral & 159 & 5.9 & & & & \\
\hline & & Agree & 1654 & 61.3 & & & & \\
\hline & & $\begin{array}{l}\text { Strongly } \\
\text { agree }\end{array}$ & 887 & 32.9 & & & & \\
\hline \multirow{5}{*}{8} & \multirow{5}{*}{$\begin{array}{l}\text { The family's } \\
\text { follow-up of their } \\
\text { children at } \\
\text { universities }\end{array}$} & $\begin{array}{l}\text { Strongly } \\
\text { disagree }\end{array}$ & - & - & \multirow{5}{*}{4.58} & \multirow{5}{*}{.508} & \multirow{5}{*}{3} & \multirow{5}{*}{ High } \\
\hline & & Disagree & - & - & & & & \\
\hline & & Neutral & 19 & .7 & & & & \\
\hline & & Agree & 1106 & 41.0 & & & & \\
\hline & & $\begin{array}{l}\text { Strongly } \\
\text { agree }\end{array}$ & 1647 & 61.0 & & & & \\
\hline \multirow{5}{*}{9} & \multirow{5}{*}{$\begin{array}{l}\text { Spreading the spirit } \\
\text { of dialogue and } \\
\text { discussion among } \\
\text { the family members }\end{array}$} & $\begin{array}{l}\text { Strongly } \\
\text { disagree }\end{array}$ & - & - & \multirow{5}{*}{4.54} & \multirow{5}{*}{.540} & \multirow{5}{*}{6} & \\
\hline & & Disagree & - & - & & & & High \\
\hline & & Neutral & 58 & 58 & & & & \\
\hline & & Agree & 1125 & 1125 & & & & \\
\hline & & $\begin{array}{l}\text { Strongly } \\
\text { agree }\end{array}$ & 1517 & 1517 & & & & \\
\hline & $\begin{array}{l}\text { Activating the } \\
\text { parents' authority }\end{array}$ & $\begin{array}{l}\text { Strongly } \\
\text { disagree }\end{array}$ & - & - & & & & \\
\hline 10 & and their role in & Disagree & - & - & & & & High \\
\hline & taking the critical & Neutral & 158 & 5.9 & 4.56 & .603 & 4 & \\
\hline & decisions & Agree & 876 & 32.4 & & & & \\
\hline & & $\begin{array}{l}\text { Strongly } \\
\text { agree }\end{array}$ & 1666 & 61.7 & & & & \\
\hline & $\begin{array}{l}\text { The family's } \\
\text { interest in forming }\end{array}$ & $\begin{array}{l}\text { Strongly } \\
\text { disagree }\end{array}$ & - & - & & & & High \\
\hline 11 & an ethical system & Disagree & - & - & & & & \\
\hline & generated from the & Neutral & 38 & 1.4 & & & & \\
\hline & Islamic values, & Agree & 1149 & 42.6 & & & & \\
\hline & $\begin{array}{c}\text { traditions and } \\
\text { customs like } \\
\text { honesty, virtue, } \\
\text { etc... }\end{array}$ & $\begin{array}{l}\text { Strongly } \\
\text { agree }\end{array}$ & 1513 & 56.0 & 4.55 & .525 & 5 & \\
\hline & The family's & $\begin{array}{l}\text { Strongly } \\
\text { disagree }\end{array}$ & - & - & 4.41 & .600 & & \\
\hline
\end{tabular}




\begin{tabular}{|c|c|c|c|c|c|c|c|c|}
\hline \multirow[t]{4}{*}{12} & \multirow{4}{*}{$\begin{array}{l}\text { continuous follow- } \\
\text { up of children, } \\
\text { understanding } \\
\text { their problems and } \\
\text { trying to help them } \\
\text { solve such } \\
\text { problems in a } \\
\text { proper way. }\end{array}$} & Disagree & - & - & & & \multirow{4}{*}{10} & \multirow{4}{*}{ High } \\
\hline & & Neutral & 159 & 5.9 & & & & \\
\hline & & Agree & 1272 & 47.1 & & & & \\
\hline & & $\begin{array}{l}\text { Strongly } \\
\text { agree }\end{array}$ & 1269 & 47.0 & & & & \\
\hline \multirow[t]{5}{*}{13} & $\begin{array}{l}\text { Monitoring and } \\
\text { controlling means }\end{array}$ & $\begin{array}{l}\text { Strongly } \\
\text { disagree }\end{array}$ & - & - & \multirow{5}{*}{4.52} & \multirow{5}{*}{.540} & \multirow{5}{*}{7} & \multirow{5}{*}{ High } \\
\hline & of social media by & Disagree & - & - & & & & \\
\hline & explaining that all & Neutral & 56 & 2.1 & & & & \\
\hline & what they want & Agree & 1195 & 44.3 & & & & \\
\hline & $\begin{array}{l}\text { through these sites } \\
\text { must be examined }\end{array}$ & $\begin{array}{l}\text { Strongly } \\
\text { agree }\end{array}$ & 1449 & 53.7 & & & & \\
\hline \multirow{5}{*}{14} & \multirow{5}{*}{$\begin{array}{l}\text { The family's } \\
\text { orientation of } \\
\text { children to select } \\
\text { their friends } \\
\text { wisely as this has } \\
\text { a huge impact in } \\
\text { influencing } \\
\text { children's behavior } \\
\text { and acquiring } \\
\text { several values } \\
\text { from them }\end{array}$} & $\begin{array}{l}\text { Strongly } \\
\text { disagree }\end{array}$ & - & - & \multirow[b]{5}{*}{4.39} & \multirow[b]{5}{*}{.568} & \multirow{5}{*}{11} & \multirow{5}{*}{ High } \\
\hline & & Disagree & - & - & & & & \\
\hline & & Neutral & 114 & 4.2 & & & & \\
\hline & & Agree & 1423 & 52.7 & & & & \\
\hline & & $\begin{array}{l}\text { Strongly } \\
\text { agree }\end{array}$ & 1163 & 43.1 & & & & \\
\hline \multirow{5}{*}{15} & \multirow[t]{5}{*}{$\begin{array}{l}\text { Respecting others' } \\
\text { opinion }\end{array}$} & $\begin{array}{l}\begin{array}{l}\text { Strongly } \\
\text { disagree }\end{array} \\
\end{array}$ & - & - & \multirow{5}{*}{4.41} & \multirow{5}{*}{.600} & \multirow{5}{*}{10} & \multirow{5}{*}{ High } \\
\hline & & Disagree & - & - & & & & \\
\hline & & Neutral & 159 & 5.9 & & & & \\
\hline & & Agree & 1272 & 47.1 & & & & \\
\hline & & $\begin{array}{l}\text { Strongly } \\
\text { agree }\end{array}$ & 1269 & 47.0 & & & & \\
\hline \multirow{5}{*}{16} & \multirow{5}{*}{$\begin{array}{l}\text { Providing family } \\
\text { ties between the } \\
\text { family members }\end{array}$} & $\begin{array}{l}\text { Strongly } \\
\text { disagree }\end{array}$ & - & - & \multirow{5}{*}{4.27} & \multirow{5}{*}{.548} & \multirow{5}{*}{12} & \multirow{5}{*}{ High } \\
\hline & & Disagree & - & - & & & & \\
\hline & & Neutral & 159 & 5.9 & & & & \\
\hline & & Agree & 1654 & 61.3 & & & & \\
\hline & & $\begin{array}{l}\text { Strongly } \\
\text { agree }\end{array}$ & 887 & 32.9 & & & & \\
\hline \multirow{5}{*}{17} & $\begin{array}{l}\text { Mutual respect } \\
\text { between couples }\end{array}$ & $\begin{array}{l}\text { Strongly } \\
\text { disagree }\end{array}$ & - & - & & & & \\
\hline & & Disagree & - & - & & & & \\
\hline & & Neutral & 117 & 4.3 & 4.41 & .573 & 10 & High \\
\hline & & Agree & 1361 & 50.4 & & & & \\
\hline & & $\begin{array}{c}\text { Strongly } \\
\text { agree }\end{array}$ & 1222 & 45.3 & & & & \\
\hline & Proving a family & $\begin{array}{l}\text { Strongly } \\
\text { disagree }\end{array}$ & - & - & & & & \\
\hline 18 & atmosphere of & Disagree & - & - & 458 & 549 & & \\
\hline & love & Neutral & 78 & 2.9 & 4.58 & .549 & 3 & High \\
\hline & & Agree & 975 & 36.1 & & & & \\
\hline & & Strongly & 1647 & 61.0 & & & & \\
\hline
\end{tabular}




\begin{tabular}{|c|c|c|c|c|c|c|c|c|}
\hline & & agree & & & & & & \\
\hline \multirow[t]{5}{*}{19} & \multirow{5}{*}{$\begin{array}{l}\text { Awareness of the } \\
\text { children's ideas } \\
\text { and how far they } \\
\text { adhere to them }\end{array}$} & $\begin{array}{l}\text { Strongly } \\
\text { disagree }\end{array}$ & - & - & \multirow{5}{*}{4.45} & \multirow{5}{*}{.594} & \multirow{5}{*}{9} & \multirow{5}{*}{ High } \\
\hline & & Disagree & - & - & & & & \\
\hline & & Neutral & 141 & 5.2 & & & & \\
\hline & & Agree & 1198 & 44.4 & & & & \\
\hline & & $\begin{array}{c}\text { Strongly } \\
\text { agree }\end{array}$ & 1361 & 50.4 & & & & \\
\hline \multirow{5}{*}{20} & \multirow{5}{*}{$\begin{array}{l}\text { Doing the best to } \\
\text { spare the family } \\
\text { all marital } \\
\text { problems }\end{array}$} & $\begin{array}{l}\text { Strongly } \\
\text { disagree }\end{array}$ & - & - & \multirow{5}{*}{4.56} & \multirow{5}{*}{.603} & \multirow{5}{*}{4} & \multirow{5}{*}{ High } \\
\hline & & Disagree & - & - & & & & \\
\hline & & Neutral & 158 & 5.9 & & & & \\
\hline & & Agree & 876 & 32.4 & & & & \\
\hline & & $\begin{array}{c}\text { Strongly } \\
\text { agree }\end{array}$ & 1666 & 61.7 & & & & \\
\hline \multirow{5}{*}{21} & \multirow{5}{*}{$\begin{array}{c}\text { The parents' } \\
\text { fulfilling their } \\
\text { duties and bearing } \\
\text { their } \\
\text { responsibilities }\end{array}$} & $\begin{array}{l}\text { Strongly } \\
\text { disagree }\end{array}$ & $\begin{array}{l}- \\
-\end{array}$ & - & \multirow{5}{*}{4.49} & \multirow{5}{*}{.585} & \multirow{5}{*}{8} & \multirow{5}{*}{ High } \\
\hline & & Disagree & - & - & & & & \\
\hline & & Neutral & 124 & 4.6 & & & & \\
\hline & & Agree & 1124 & 41.6 & & & & \\
\hline & & $\begin{array}{c}\text { Strongly } \\
\text { agree }\end{array}$ & 1452 & 53.8 & & & & \\
\hline & $\begin{array}{l}\text { The first domain } \\
\text { as a whole }\end{array}$ & & \multicolumn{3}{|c|}{ Mean = 4} & \multicolumn{3}{|c|}{$\begin{array}{c}\text { 0.331:.Standard } \\
\text { Dev. }=\end{array}$} \\
\hline
\end{tabular}

It is clear from table (2) that the social domain degree was high with a mean of (4.506) and a standard deviation of (0.331). The first rank was for the paragraph about( The family doing its main function of upbringing and socialization) with a mean of (0.331) and a standard deviation of (0.495) followed by the two paragraphs about (Increasing patriotism and defend country home against dangers contributes to consolidating intellectual security, reinforcing values of cooperation among the family members with a mean of (0. 459$)$ for the two paragraphs respectively and a standard deviation of (.506) , (.547). The two paragraphs about (Enhancing authentic values like strong relationship with relatives, particularly parents, providing strong family ties between the family members) with a mean of (4.27) for the two paragraphs respectively and with a standard deviation of (.561) , (.548) respectively.

Secondly: The cultural domain:

The frequencies percentages, means, standard deviations and rank for each of the cultural domain paragraphs. The results were as follows: 
Table (3) shows the frequencies, percentages, mean, standard deviation and rank for

\begin{tabular}{|c|c|c|c|c|c|c|c|c|}
\hline $\begin{array}{c}\text { Paragraph } \\
\text { no. }\end{array}$ & Paragraph text & Answer Level & Freq. & $\%$ & $\bar{X}$ & St.d & Order & value \\
\hline \multirow{5}{*}{1} & \multirow{5}{*}{$\begin{array}{l}\text { Accompanying } \\
\text { family } \\
\text { members when } \\
\text { attending } \\
\text { cultural events }\end{array}$} & $\begin{array}{l}\text { Strongly } \\
\text { disagree }\end{array}$ & - & - & \multirow{5}{*}{4.39} & \multirow{5}{*}{.568} & \multirow{5}{*}{6} & \multirow{5}{*}{ فرت } \\
\hline & & Disagree & - & - & & & & \\
\hline & & Neutral & 114 & 4.2 & & & & \\
\hline & & Agree & 1423 & 52.7 & & & & \\
\hline & & Strongly agree & 1163 & 43.1 & & & & \\
\hline \multirow{5}{*}{2} & \multirow{5}{*}{$\begin{array}{l}\text { Enhancing } \\
\text { skills, } \\
\text { developing } \\
\text { capacities and } \\
\text { talents }\end{array}$} & $\begin{array}{l}\text { Strongly } \\
\text { disagree }\end{array}$ & - & - & \multirow{5}{*}{4.58} & \multirow{5}{*}{.508} & \multirow{5}{*}{3} & \multirow{5}{*}{ فرت } \\
\hline & & Disagree & - & - & & & & \\
\hline & & Neutral & 19 & .7 & & & & \\
\hline & & Agree & 1106 & 41.0 & & & & \\
\hline & & Strongly agree & 1575 & 58.3 & & & & \\
\hline \multirow{5}{*}{3} & \multirow{5}{*}{$\begin{array}{l}\text { Family } \\
\text { members' } \\
\text { avoiding } \\
\text { watching } \\
\text { media } \\
\text { programs that } \\
\text { calls for } \\
\text { hatred, } \\
\text { extremism or } \\
\text { oppression }\end{array}$} & $\begin{array}{l}\text { Strongly } \\
\text { disagree }\end{array}$ & & & \multirow{5}{*}{4.59} & \multirow{5}{*}{.547} & \multirow{5}{*}{2} & \multirow{5}{*}{ فرت } \\
\hline & & Disagree & & & & & & \\
\hline & & Neutral & 77 & 2.9 & & & & \\
\hline & & Agree & 951 & 35.2 & & & & \\
\hline & & Strongly agree & 1672 & 61.9 & & & & \\
\hline \multirow{5}{*}{4} & \multirow{5}{*}{$\begin{array}{l}\text { The Family } \\
\text { monitoring of } \\
\text { the quality of } \\
\text { programs } \\
\text { watched by } \\
\text { children } \\
\text { especially } \\
\text { those } \\
\text { programs } \\
\text { which praise } \\
\text { terrorism. }\end{array}$} & $\begin{array}{l}\text { Strongly } \\
\text { disagree }\end{array}$ & - & - & & & \multirow{5}{*}{3} & \multirow{5}{*}{ فرت } \\
\hline & & Disagree & - & - & & & & \\
\hline & & Neutral & 19 & .7 & & & & \\
\hline & & Agree & 1106 & 41.0 & & & & \\
\hline & & Strongly agree & 1575 & 58.3 & 4.58 & .508 & & \\
\hline \multirow{5}{*}{5} & \multirow{5}{*}{$\begin{array}{l}\text { Responding } \\
\text { wisely to } \\
\text { children's } \\
\text { questions and } \\
\text { orienting them } \\
\text { towards useful } \\
\text { things }\end{array}$} & $\begin{array}{l}\text { Strongly } \\
\text { disagree }\end{array}$ & - & - & \multirow{5}{*}{4.59} & \multirow{5}{*}{.506} & \multirow{5}{*}{2} & \multirow{5}{*}{ فرت } \\
\hline & & Disagree & - & - & & & & \\
\hline & & Neutral & 19 & .7 & & & & \\
\hline & & Agree & 1074 & 39.8 & & & & \\
\hline & & Strongly agree & 1607 & 59.5 & & & & \\
\hline \multirow{3}{*}{6} & \multirow{3}{*}{$\begin{array}{l}\text { Strengthening } \\
\text { the values of } \\
\text { moderation } \\
\text { among }\end{array}$} & $\begin{array}{l}\text { Strongly } \\
\text { disagree }\end{array}$ & - & - & & & & \\
\hline & & Disagree & - & - & 4.64 & .486 & 1 & $\Delta$ \\
\hline & & Neutral & 6 & .2 & & & & \\
\hline
\end{tabular}




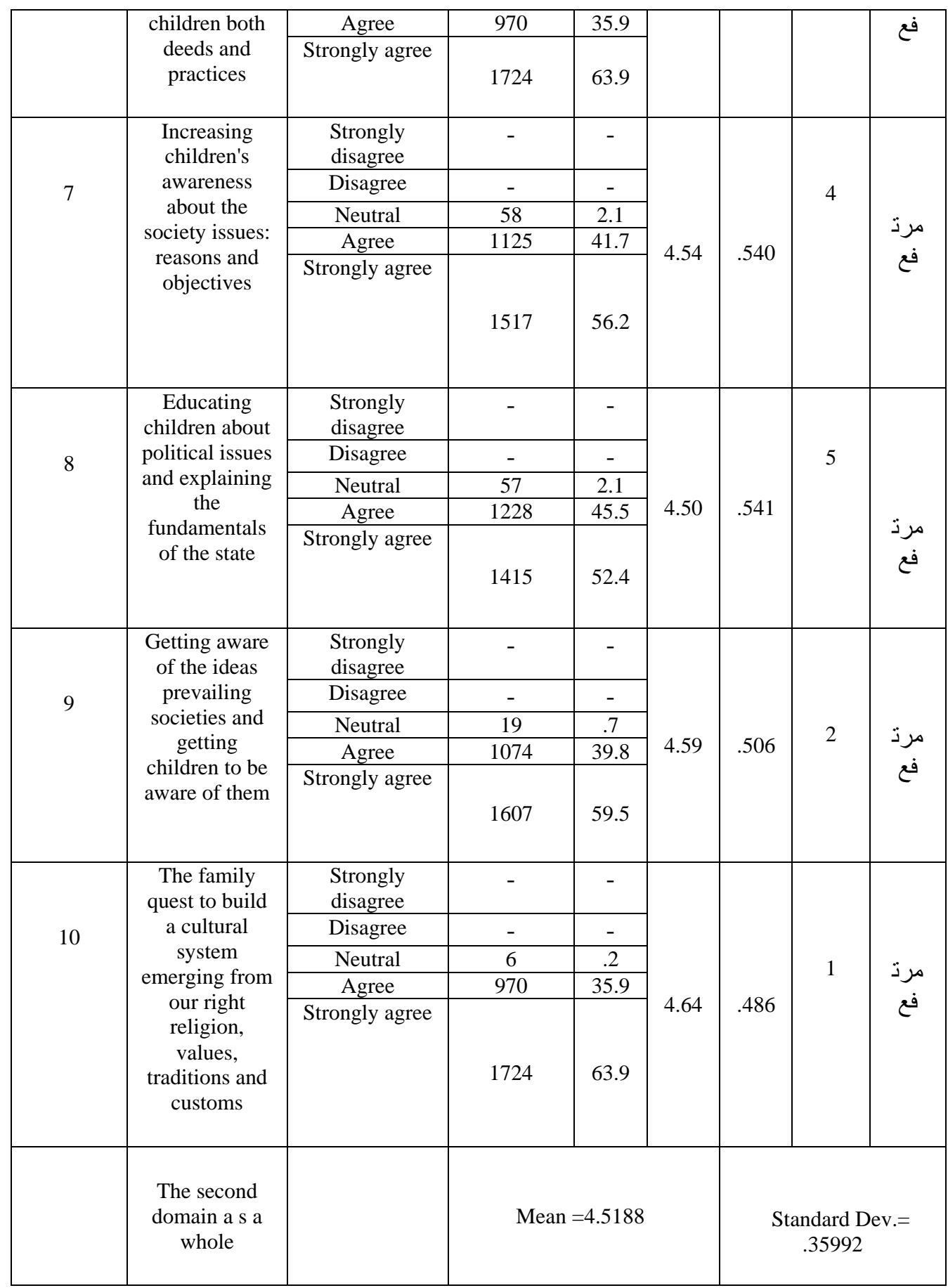

he cultural domain paragraphs 


\section{Thirdly: The Religion domain}

The frequencies percentages, means, standard deviations and rank for each of the religion domain paragraphs. The results were as follows:

Table (4) shows the frequencies, percentages, mean, standard deviation and rank for

\begin{tabular}{|c|c|c|c|c|c|c|c|c|}
\hline $\begin{array}{c}\text { Paragraph } \\
\text { no. }\end{array}$ & Paragraph text & Answer Level & Freq. & $\%$ & $\bar{X}$ & St.d & Order & Rank \\
\hline \multirow{5}{*}{1} & \multirow{5}{*}{$\begin{array}{l}\text { Instilling } \\
\text { religious faith, } \\
\text { abiding to it } \\
\text { and } \\
\text { strengthening it } \\
\text { through proper } \\
\text { educational } \\
\text { methods }\end{array}$} & $\begin{array}{l}\text { Strongly } \\
\text { disagree }\end{array}$ & - & - & \multirow{5}{*}{4.49} & \multirow{5}{*}{.514} & \multirow{5}{*}{3} & \multirow{5}{*}{ High } \\
\hline & & Disagree & - & - & & & & \\
\hline & & Neutral & 19 & .7 & & & & \\
\hline & & Agree & 1331 & 49.3 & & & & \\
\hline & & Strongly agree & 1350 & 50.0 & & & & \\
\hline \multirow{5}{*}{2} & \multirow{5}{*}{$\begin{array}{l}\text { Accompanying } \\
\text { children when } \\
\text { going to the } \\
\text { mosque and } \\
\text { attending } \\
\text { religious } \\
\text { lessons and } \\
\text { speeches }\end{array}$} & $\begin{array}{l}\text { Strongly } \\
\text { disagree }\end{array}$ & - & - & \multirow[b]{5}{*}{4.45} & \multirow[b]{5}{*}{.594} & & \multirow{5}{*}{ High } \\
\hline & & Disagree & - & - & & & & \\
\hline & & Neutral & 141 & 5.2 & & & & \\
\hline & & Agree & 1198 & 44.4 & & & & \\
\hline & & Strongly agree & & & & & 4 & \\
\hline \multirow{5}{*}{3} & \multirow{5}{*}{$\begin{array}{c}\text { Getting } \\
\text { children aware } \\
\text { of the dangers } \\
\text { of declaring } \\
\text { others } \\
\text { disbelievers }\end{array}$} & $\begin{array}{l}\text { Strongly } \\
\text { disagree }\end{array}$ & - & - & \multirow{5}{*}{4.55} & \multirow{5}{*}{.511} & \multirow{5}{*}{2} & \multirow{5}{*}{ High } \\
\hline & & Disagree & - & - & & & & \\
\hline & & Neutral & 19 & .7 & & & & \\
\hline & & Agree & 1169 & 43.3 & & & & \\
\hline & & Strongly agree & 1512 & 56.0 & & & & \\
\hline \multirow[t]{5}{*}{4} & \multirow{5}{*}{$\begin{array}{l}\text { The family } \\
\text { quest to form } \\
\text { the right belief } \\
\text { at an early age }\end{array}$} & $\begin{array}{l}\text { Strongly } \\
\text { disagree }\end{array}$ & - & - & \multirow{5}{*}{4.56} & \multirow{5}{*}{.511} & \multirow{5}{*}{1} & \multirow{5}{*}{ High } \\
\hline & & Disagree & - & - & & & & \\
\hline & & Neutral & 19 & .7 & & & & \\
\hline & & Agree & 1163 & 43.1 & & & & \\
\hline & & Strongly agree & 1518 & 56.2 & & & & \\
\hline \multirow{6}{*}{5} & $\begin{array}{l}\text { The family } \\
\text { members' }\end{array}$ & $\begin{array}{l}\text { Strongly } \\
\text { disagree }\end{array}$ & - & - & \multirow{5}{*}{4.44} & \multirow{5}{*}{.592} & \multirow{5}{*}{5} & \multirow{5}{*}{ High } \\
\hline & performing & Disagree & 1 & .0 & & & & \\
\hline & worship & Neutral & 137 & 5.1 & & & & \\
\hline & activities & Agree & 1231 & 45.6 & & & & \\
\hline & continually & Strongly agree & 1331 & 49.3 & & & & \\
\hline & $\begin{array}{l}\text { The third } \\
\text { domain as a } \\
\text { whole }\end{array}$ & & \multicolumn{3}{|c|}{ Mean =4.5188 } & \multicolumn{3}{|c|}{ Standard dev. $=.35992$} \\
\hline
\end{tabular}


It is clear from table (4) that the religion domain degree was high. The mean of which was (4.5188) as a whole, and with a standard deviation of (.35992). The paragraph which states (The family quest to form truthful beliefs among children at an early age) took the first rank with a mean of (4.56) and a standards deviation of (.511). Whereas the paragraph which states ( spreading awareness among children about the perils of extremist beliefs) occupied the second rank with a mean of (4.55) and a standard deviation of(.511). The paragraph which states (accompanying children to the mosque and attending lessons and religious breaches) took the last rank with a mean of (4.45) and a standard deviation of (.594)

\section{Conclusion}

The study came up with the following conclusions:

- The study showed that the three domains (cultural, social, religious) were of a high degree, and the highest degree was for the cultural domain with a mean of (4.5188) and a standard deviation of (.35992) followed by the social domain with a mean of ( 4.5061) and a standard deviation of (.33102) whereas the religious domain occupied the last rank with a mean of (4.4989) and a standard deviation of (.40374). The total values for the three domains together was high with a mean of (4.5087) and a standard deviation of $(.34179)$.

- The study showed that the degree of the social domain was high. The mean of which was (4.506) and the standard deviation was (0.331). The paragraph which states( The family doing its main job in in education and socialization) occupied the first rank with a mean of (4.64) and a standard deviation of (0.495) .

- The study showed that the degree of the cultural domain was high. The mean of which was (4.5188). and the standard deviation was (0. 35992) . The two paragraphs that state (The family's seeking to build a cultural system of thoughts derived from our religion, values, traditions and customs and consolidating the values of moderation among children both in deeds and practice) came in the first rank with a mean of (4.64) for the two paragraphs respectively and with a standard deviation of (.486) for the two paragraphs respectively.

- The study showed that the degree of the religious domain was high. The mean of which as a whole was (4.5188) and a standard deviation of (.35992). The paragraph which states( the family seeking to form the right belief at an early age) occupied the first rank with a mean of (4.56) and a standard deviation of (.511). 


\section{Recommendations:}

According to the study conclusions, the researcher recommends the following:

- Increasing security awareness among children and explaining the perils of extremism and terrorism on the security of society.

- Building an integrated intellectual system based on consolidating the principles of moderation in beliefs, deeds and sayings. This intellectual system should be a product of cooperative work of all institutions of socialization in order to consolidate intellectual security for families.

- The necessity for the families to follow up their children affairs continually in order to protect them against the perils of intellectual extremism.

- The necessity for cooperation between the security, education and religion institutions in order to fulfil intellectual security.

\section{References:}

Ashareefain, Matalqa, Masa'da, (2015) Promoting Intellectual Security in the content of educational Curricula: A theoretical study, Journal of Scientific Research, The Research and studies' Center at King Fahd College, ( 2460 , 123-157) Prince Nayef University for Security Socities, first edition

Hreiz, Mohammad Alhabeeb, (2005), The reality of Intellectual Security, Center of Intellectual Studies and Research ,Nayef Arab University for Security Sciences, first edition, Faculty of Education, Intellectual Security in the Islamic Educational syllabuses for the Secondary Stage, a unpublished Master's thesis, University of Umm Al qura, The Kingdom of Saudi Arabia Taleb, Hasan Mubarak, (2005), The Family and its Role in Protecting its Children against Behavioral Deviations, Center of Intellectual Studies and Research ,Nayef Arab University for Security Sciences, first edition

Al Amar, Ma'n Khaleel, (1994), Family sociology, Ashorouq publishers, Amman, $2^{\text {nd }}$ edition.

Nasser, Mohammad Mohammad, (2010) , " Security and Development), Alobaikan Library, KSA. Arriyadh, alJehni, Ali Bin Fayez, (2004), The Role of the Family in Promoting Intellectual Security, Magazine of Police Thought, The United Arab Emirates )12 ( 4 , P 155 - 190 Article) 